\title{
OPTIMISATION OF MECHANICAL PROPERTIES OF 18\%Ni350 GRADE MARAGING STEEL USING NOVEL HEAT TREATMENT
}

\begin{abstract}
The paper presents results of examinations of properties and microstructure of maraging steel grade MS350 (18Ni350) produced by a novel heat treatment method called ,short-time ageing”. It has been found that maraging steel after application of the short-time ageing achieves unique properties, in particular good combination of strength and impact toughness. After short-time ageing for time of heating up to 600 seconds at temperature of $550^{\circ} \mathrm{C}$ hardness in the range from 48 to $56 \mathrm{HRC}$, tensile strength ranging from 2000 to $2250 \mathrm{MPa}$, yield strength from 1930 to $2170 \mathrm{MPa}$ and total elongation in the range 7-8\% as well as notch impact toughness of $20 \mathrm{~J} / \mathrm{cm}^{2}$ at temperature minus $40^{\circ} \mathrm{C}$ were obtained. Results of microstructure examination in transmission electron microscope (TEM) with application of high resolution technique (HRTEM) have shown presence of $\mathrm{Ni}_{3} \mathrm{Mo}$ nano-precipitates of orthorhombic crystallographic structure. Precipitates were characterized by rod-like shape and were homogenously distributed in martensitic matrix of steel with high density of dislocations. The average size of cross-section of precipitates was ca. $4 \mathrm{~nm}$ while length reached several dozen of nm.
\end{abstract}

Keywords: maraging steel, short-time ageing, mechanical properties, microstructure, HRTEM

\section{Introduction}

Ultra-high strength MS350 maraging steel achieves tensile strength at the level of $2400 \mathrm{MPa}$ and yield strength of $2300 \mathrm{MPa}$ at total elongation ca. $7 \%$ and impact toughness at temperature of $-40^{\circ} \mathrm{C}$ at the level of $10 \mathrm{~J}$. Standard parameters of ageing are: temperature in the range $470-500^{\circ} \mathrm{C}$ and time of 3-4 hours. The results of research on kinetics of precipitation process in dispersion strengthened steels obtained so far by authors of the present paper indicate that high strength and simultaneously increased ductility may be obtained by application of short-time and high temperature ageing [1,2]. According to the theory of nucleation and growth of precipitates application of the increased temperature of ageing may result in formation of numerous nuclei while short time of the process may prevent from growth thereof. A crucial issue is in this case stability of the obtained type of microstructure and properties of material in operating conditions of the steel products.

The paper presents results of the effect of increased temperature and short-time ageing in reference to standard parameters on ductility of MS350 maraging steel at required strength level. Ageing cycles were developed for temperatures of $480^{\circ} \mathrm{C}$ and $550^{\circ} \mathrm{C}$ as well as examinations of the microstructure and mechanical properties following application of short-time heat treatment were conducted.

\section{Processes occurring during early stages of ageing of maraging steel}

Processes of precipitation, growth and evolution of particles strengthening the matrix of maraging steel have been the subject of research from the very beginning of development and application of this steel class, i.e. from early 1960-s [3-11]. Mechanism and kinetics of precipitation depending on the chemical composition of maraging steel and parameters of heat treatment and in particular the early stages of precipitate strengthening were a subject of numerous research studies [12-19] and have not been fully understood till date. Description of these phenomena is complicated due to changes in chemical composition and crystallographic structure of strengthening nano-particles. Moreover, there is no explicit description and explanation of phenomena occurring during early stages of precipitation processes. Authors of studies $[8,9]$ have formulated a hypothesis concerning homogenous nucleation, according to which this process may occur in the conditions of strong supersaturation of martensitic matrix despite high density of dislocation in lath martensite which are preferential locations of precipitation nucleation. Unless marked otherwise, the alloy composition in this paper is given in wt.\%. Tewari and others [12] conducted examinations of precipitates evolution in MS350 maraging steel using the small angle X-ray scattering and transmission electron microscopy techniques. The 
obtained results indicated the possibility of presence of two types of time-temperature-transformation (TTT) curves describing the process of nucleation and growth of precipitates: one for particles of $\omega$ phase and the second for $\mathrm{Ni}_{3} \mathrm{Mo}$ phase. Authors of the study [12] indicated the time of the beginning of $\mathrm{Ni}_{3} \mathrm{Mo}$ particles precipitation in MS350 maraging steel (18Ni-12.5Co-4.2Mo-1.7Ti) which at the temperature of ageing of $510^{\circ} \mathrm{C}$ is ca. 30 minutes. At temperatures below $450^{\circ} \mathrm{C}$ the time of the beginning of $\mathrm{Ni}_{3} \mathrm{Mo}$ phase precipitation is much longer and averages several dozen hours. Guo and others [13] determined the time of the beginning of precipitation in $\mathrm{C} 250$ (18Ni-8Co-5Mo-0.5Ti) maraging steel by means of differential scanning calorimetry. The authors have shown that during ageing at temperature of $482^{\circ} \mathrm{C}$ the time of the beginning of precipitation is ca. 30 seconds while after 1 hour precipitation process is finished. A sample subjected to ageing at temperature of $482^{\circ} \mathrm{C}$ during 1 hour reached hardness of ca. $500 \mathrm{HV}$ (hardness after supersaturation was $300 \mathrm{HV}$ ). Pardal and others conducted examination of precipitation process in 300 maraging steel $(17.9 \mathrm{Ni}-9.4 \mathrm{Co}-4.8 \mathrm{Mo}-0.8 \mathrm{Ti})$ aged in temperature range $440-650^{\circ} \mathrm{C}[14]$. The authors have shown that following ageing at temperature of $560^{\circ} \mathrm{C}$ during 1 hour hardness reaches $600 \mathrm{HV}$. Sha showed that early stages of precipitation process may be described by means of Jonson-Mehl-Avrami equation [15]. The author has found that hardness of C-300 (18.5Ni-9Co4.8Mo-0.6Ti) maraging steel subjected to ageing at temperature of $420^{\circ} \mathrm{C}$ during time from 160 seconds to 25 minutes increased by ca. $100 \mathrm{HV}$. Li and Yin [16] carried out examinations of $18 \mathrm{Ni}(350)$ maraging steel (18Ni-12Co-4.5Mo-1.3Ti) subjected to ageing at temperature of $500^{\circ} \mathrm{C}$ during time of: $2,5,15,30$ and 60 minutes. The authors were found that precipitation process is preceded by redistribution of atoms which form zones enriched with Co and Ni, Mo and Ti. The process of elements redistribution is dynamic during initial stage of ageing and slows down as the transformation progresses. Rajkumara and others [17] have found that hardness of M250 maraging steel (17.89Ni-8.16Co$4.88 \mathrm{Mo}-0.43 \mathrm{Ti}$ ) increased as a result of ageing at temperature $482^{\circ} \mathrm{C}$ during 15 minutes by $150 \mathrm{HVN}$ (from 360 to $510 \mathrm{HVN}$ ). Hardness of M250 steel increased along with time of ageing and following reaching the maximum went down at longer time of heat treatment [17]. Based on the results of examinations using TEM it was found that initial growth of hardness during ageing below 3 hours arises from formation of precipitates of $\mathrm{Ni}_{3} \mathrm{Mo}$ inter-metallic phases. Further increase in hardness in the time range from 3 to 40 hours is related to additional precipitation of $\mathrm{Fe}_{2} \mathrm{Mo}$ nano-particles. Published works on the short-time ageing (for the time below 30 minutes) were completed on thin samples which often made impossible to carry out tensile tests to determine mechanical properties. Changes in the distribution of elements in matrix of experimental alloy Fe-20Ni-1.8Mn$1.5 \mathrm{Ti}-0.59 \mathrm{Al}$ and examination of the process of precipitation, microstructure and mechanical properties of the steel aged at the temperature of $550^{\circ} \mathrm{C}$ were conducted under the study [18]. The effect of alloy matrix hardening was noted as early as following 5 seconds of ageing at $550^{\circ} \mathrm{C}$. Material hardness increased by $200 \mathrm{HVN}$ while yield strength by ca. $215 \mathrm{MPa}$ and reached 900
$\mathrm{MPa}$ (mechanical properties were determined from the relation based on thin samples hardness measurement). The authors stated that hardening comes from clusters enriched with $\mathrm{Ni}, \mathrm{Ti}, \mathrm{Al}$ and $\mathrm{Mn}$ atoms. Presence of single $\gamma-\mathrm{Ni}_{3}$ Ti rod-like precipitates was noted following 60 seconds of ageing at temperature of $550^{\circ} \mathrm{C}$. This stage was associated with continuous growth of hardness until reaching the maximum following 600 seconds of holding at temperature of $550^{\circ} \mathrm{C}$. Shekhter and others [19] carried out examinations of precipitation in alloy $\mathrm{Fe}-25.3 \mathrm{Ni}-1.7 \mathrm{Ti}$ in an undeformed state and following cold deformation prior to ageing. The authors have found that following heating during 5 seconds at temperature of $550^{\circ} \mathrm{C}$ the material showed good combination of strength and ductility coming from clusters enriched with $\mathrm{Ni}$ and Ti atoms which hindered movement of dislocations.

\section{Material}

Research material was manufactured in laboratory conditions. Ingots of cross section $60 \times 150 \mathrm{~mm}$ and weight ca. $70 \mathrm{~kg}$ of MS350 maraging steel (18Ni350) were melted in vacuum furnace and cast into moulds. Chemical compositions of laboratory heats are given in Table 1. The ingots were subjected to homogenisation heat treatment at temperature of $1250^{\circ} \mathrm{C}$ during 24 hours in argon atmosphere. The next stage of material preparation was hot rolling of ingots to plates of thickness ranging from 4 to $12 \mathrm{~mm}$. Plates sections following solution heat treatment at temperature of $850^{\circ} \mathrm{C}$ during 30 minutes and water cooling were used for preparation of samples for final heat treatment.

TABLE 1

Chemical composition of examined material (MS350 maraging steel), weight $\%$

\begin{tabular}{|c|c|c|c|c|c|c|c|c|c|c|}
\hline \hline $\begin{array}{c}\text { Heat } \\
\text { no }\end{array}$ & $\mathbf{C}$ & $\mathbf{M n}$ & $\mathbf{S i}$ & $\mathbf{P}$ & $\mathbf{S}$ & $\mathbf{N i}$ & $\mathbf{C o}$ & $\mathbf{M o}$ & $\mathbf{T i}$ & $\mathbf{A l}_{\text {tot. }}$ \\
\hline 1 & 0.007 & 0.05 & 0.02 & 0.010 & $<0.01$ & 18.0 & 12.8 & 4.6 & 1.6 & 0.01 \\
\hline 2 & 0.007 & 0.05 & $<0.05$ & 0.007 & $<0.01$ & 18.0 & 13.1 & 4.5 & 1.8 & 0.02 \\
\hline 3 & 0.008 & $<0.05$ & $<0.05$ & 0.008 & $<0.01$ & 18.1 & 12.8 & 4.2 & 1.8 & 0.02 \\
\hline
\end{tabular}

\section{Experimental procedures}

Ageing of maraging steel in temperature range $400-550^{\circ} \mathrm{C}$ for short-time (from 15 to 600 seconds ) was conducted in a Gleeble 3800 simulator. Cylindrical samples of diameter $6 \mathrm{~mm}$ and height $7 \mathrm{~mm}$ were prepared for tests. Two tests were conducted for each variant of heat treatment. One sample was used for hardness measurements and examinations of microstructure and the second for static uniaxial compression at room temperature. Samples subjected to standard ageing at $480^{\circ} \mathrm{C}$ for time from 30 minutes to 8 hours were also prepared for compression tests. Based on compression curves the value of yield strength $\left(R_{C}\right)$ was determined. $R_{C}$ corresponds to stress at strain value of 0.002 . Ductility of the steel was assessed based on the value of strain at the moment of crack formation and on the basis of observations 
of side surfaces of the compressed samples. Parameters of heat treatment and compression tests conducted in Gleeble simulator were as follows: ageing temperatures $T s=400^{\circ} \mathrm{C} ; 480^{\circ} \mathrm{C}$ and $550^{\circ} \mathrm{C}$; ageing times $t s=15 \mathrm{~s} ; 30 \mathrm{~s} ; 60 \mathrm{~s} ; 120 \mathrm{~s} ; 300 \mathrm{~s}$ and $600 \mathrm{~s}$, heating rate to $T_{s}$ was $10 \mathrm{~K} / \mathrm{s}$, cooling rate to room temperature was ca. $10 \mathrm{~K} / \mathrm{s}$; value of strain at room temperature $\varepsilon=1.2$; strain rate $0.01 \mathrm{~s}^{-1}$.

In order to examine the effect of heating and cooling rate, experiments of short-time and impulse heating of samples in a dilatometer were conducted using heating rate of ca. 500-600 $\mathrm{K} / \mathrm{s}$ and cooling rate of ca. $400 \mathrm{~K} / \mathrm{s}$. Tubular samples $\phi 4 / \phi 3 \times 10$ $\mathrm{mm}$ were used for the heat treatment. On the heat treated specimens hardness measurements were conducted. In case of tests carried out in a dilatometer heat treatment at temperatures of $480^{\circ} \mathrm{C}$ and $550^{\circ} \mathrm{C}$ was applied with application of times of 10 , 20 and 30 seconds as well as impulse heating to temperature of ageing without holding at the temperature.

The following properties were determined for the selected variants of ageing: ultimate tensile strength (UTS), yield strength (YS) and total elongation (A) in static tensile test. Samples for testing mechanical properties were prepared using two-stage heat treatment. Samples were heated in the furnace of temperature higher than the temperature of ageing; when reaching the temperature of ageing the samples were shifted to the furnace of the temperature of ageing. Heating in the furnace of temperature higher than the temperature of ageing ensured shortening the time of heating [20]. Charpy-V impact toughness was determined at room temperature $\left(+22^{\circ} \mathrm{C}\right)$ and at temperature of $-40^{\circ} \mathrm{C}$. Charpy-V impact tests were conducted on longitudinal samples cut from hot-rolled plate of thickness $10 \mathrm{~mm}$. Samples of nominal dimensions of cross section $7.5 \times 10 \mathrm{~mm}$ were used. Surface of fracture was perpendicular to the rolling direction. Hardness measurements were conducted using Rockwell HRC and Vickers methods at loads of $1 \mathrm{~kg}$ (HV1) and $10 \mathrm{~kg}$ (HV10).

Examinations of fracture surface were conducted by means of scanning electron microscope. Examination of microstructure for selected variants of short-time ageing were conducted by means of high resolution transmission electron microscope Titan 80-300. Samples for examination were prepared as thin foils by means of electrolytic thinning as well as ion thinning. Examination comprised identification of nano-areas of elements segregation as well as morphology, chemical composition and crystallographic structure of nano-precipitates.

\section{Results}

\subsection{Heat Treatment in Gleeble 3800 Simulator}

As a result of sample deformation after ageing, stressstrain curves were obtained based on which yield strength $R_{C}$ (Fig. 1, 2 and 3) was determined. Steels of highest ductility were characterised by flat compression curve which indicates minor strengthening during cold deformation and lack of cracks on side surfaces. Presence of cracks in case of material of lower ductility was reflected in compression curve by drop in stress however deformation process was continued. In the case of samples of the highest strength (subjected to standard ageing) sudden crack occurred at relatively low strain which made impossible to continue compression.

Figures 1 and 2 present compression curves for samples aged at temperature of $480^{\circ} \mathrm{C}$ during time intervals from 15 seconds to 8 hours. Samples aged during 3-8 hours showed high level of yield strength $R_{C}$ above $2500 \mathrm{MPa}$ however during compression they suddenly cracked at the value of strain below 0.3. Samples subjected to ageing during 30 and 60 minutes were characterised by the value of $R_{C}$ ca. $2300 \mathrm{MPa}$ and elevated ductility in reference to samples subjected to ageing during several hours. In these samples cracks were formed on side surfaces however the number and type thereof enabled continuation of compression to the required strain level. All samples subjected to ageing at temperature of $480^{\circ} \mathrm{C}$ during time of 15 to 600 seconds were characterised by the good ductility which

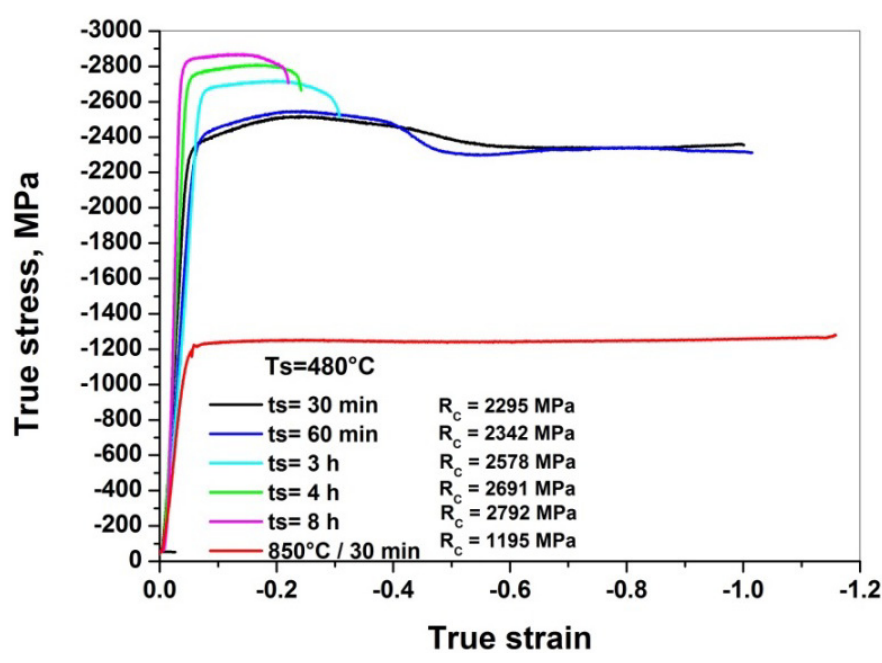

Fig. 1. Cold compression curves of MS350 maraging steel solution heat treated and aged at temperature of $480^{\circ} \mathrm{C}$ for 30 minutes to 8 hours

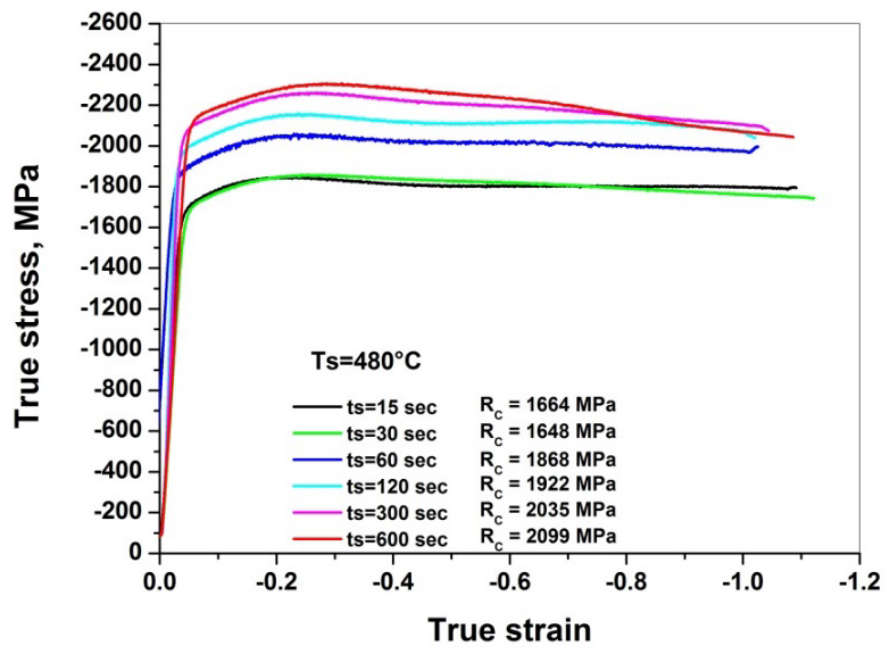

Fig. 2. Cold compression curves of MS350 maraging steel aged at temperature of $480^{\circ} \mathrm{C}$ for 15 seconds to 600 seconds 
enabled completion of the experiment (required value of strain was obtained in compression tests without sample cracking). The value of $R_{C}$ for ageing time of 600 seconds at temperature of $480^{\circ} \mathrm{C}$ was $2100 \mathrm{MPa}$.

Figure 3 presents compression curves of samples subjected to short-time ageing at temperature of $550^{\circ} \mathrm{C}$. Samples aged at temperature of $550^{\circ} \mathrm{C}$ showed the largest dynamics of growth of yield strength. Following 30 seconds the value of $R_{C}$ was $2070 \mathrm{MPa}$ and following 600 seconds it reached the level of ca. $2500 \mathrm{MPa}$ - comparable to the material after standard ageing.

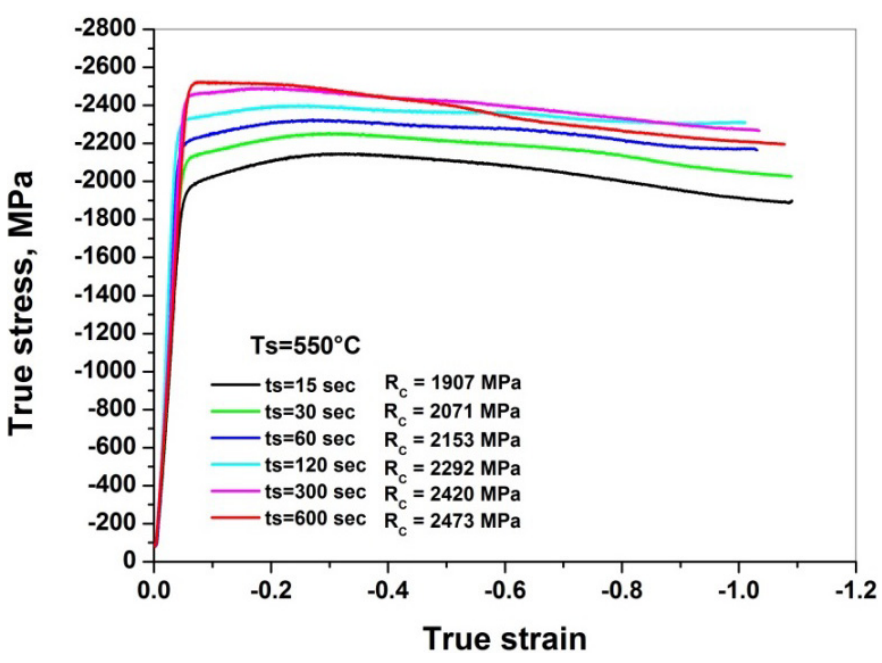

Fig. 3. Cold compression curves of MS350 maraging steel aged at temperature of $550^{\circ} \mathrm{C}$ for 15 seconds to 600 seconds

Figure 4 presents changes in the value of $R_{C}$ and the increase in $R_{C}$ during ageing at temperature of $480^{\circ} \mathrm{C}$ in reference to the solution treated state. The data shows that after 300 seconds of ageing the value of $R_{C}$ exceeds $2000 \mathrm{MPa}$ which constitutes ca. $50 \%$ of $R_{C}$ obtained after 3 hours. Figure 5 presents the values of yield strength as well as its growth during ageing at temperature of $550^{\circ} \mathrm{C}$. Diagrams in Fig. 5 show that at temperature of $550^{\circ} \mathrm{C}$ the process of precipitation strengthening is very dynamic and intensive. It was estimated that after ca. 20 seconds the yield strength exceeds $2000 \mathrm{MPa}$. Samples subjected to ageing at temperature of $550^{\circ} \mathrm{C}$ during time from a dozen or so seconds up to several hundred seconds are characterised with high ductility because of lack of cracks during cold deformation.

Slight increase of $R_{C}$ to the level of $1500 \mathrm{MPa}$ occurred at ageing temperature of $400^{\circ} \mathrm{C}$ during time up to 600 seconds.

Based on the results of compression experiments it was found that beneficial properties showed the samples which after short-time ageing achieved the level of strength close to the material subjected to ageing with application of standard parameters. The shape of compression curves as well as observations of side surfaces of samples confirmed that they are deformed without crack formation. Examples of ageing parameters (temperature and time) of MS350 maraging steel and the values of yield strength obtained as a result of the applied ageing treatment as well as qualitative assessment of deformability in static cold compression tests are presented in Table 2.

TABLE 2

Selected variants of short-time ageing of MS350 maraging steel and reference standard variant

\begin{tabular}{|c|c|c|c|}
\hline $\begin{array}{c}\text { Ageing } \\
\text { temperature, } \\
T_{s},{ }^{\circ} \mathrm{C} \\
\end{array}$ & $\begin{array}{c}\text { Ageing } \\
\text { time } \\
t_{s}, \mathrm{~s} \\
\end{array}$ & $\begin{array}{c}\text { Yield strength } \\
\text { in compression } \\
R_{C}, \mathrm{MPa} \\
\end{array}$ & Deformability assessment \\
\hline 550 & 60 & 2153 & \multirow{4}{*}{$\begin{array}{c}\text { good ductility } \\
\text { (no cracks, deformation } \\
\text { completed until the value } \\
\text { of ca. } 1.1 \text { is reached) }\end{array}$} \\
\hline 550 & 120 & 2292 & \\
\hline 550 & 300 & 2420 & \\
\hline 550 & 600 & 2473 & \\
\hline 480 & 10800 & 2578 & $\begin{array}{c}\text { low ductility } \\
\text { sudden cracking at strain } \\
\text { of ca. } 0.3 \text { (reference } \\
\text { variant) }\end{array}$ \\
\hline
\end{tabular}

Hardness measurements of specimens heat treated in Gleeble 3800 simulator were carried out. Ageing curve was developed for the temperature of $480^{\circ} \mathrm{C}$ for time in the range from 15 seconds to 8 hours (Fig. 6). As a result of standard ageing at temperature of $480^{\circ} \mathrm{C}$ during time of 3-4 hours hardness of 57-58 HRC (ca. $700 \mathrm{HV}$ ) was obtained. Hardness of

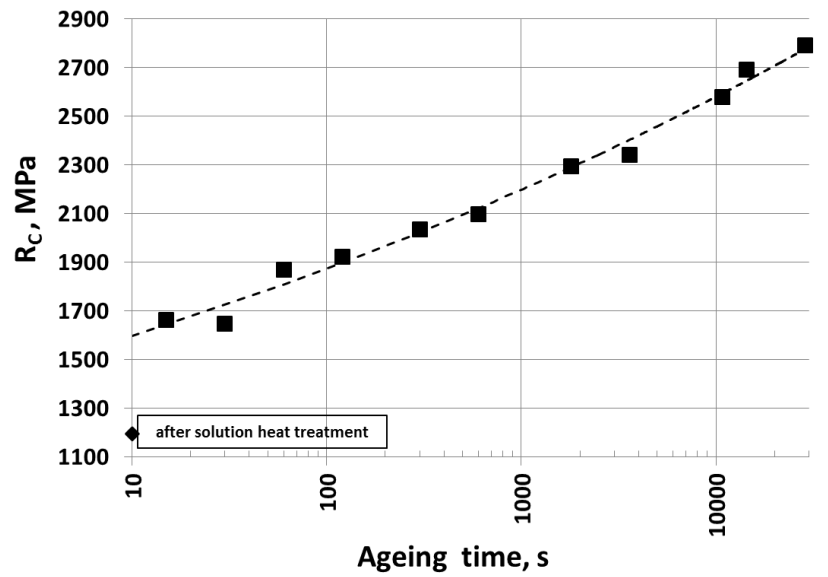

(a)

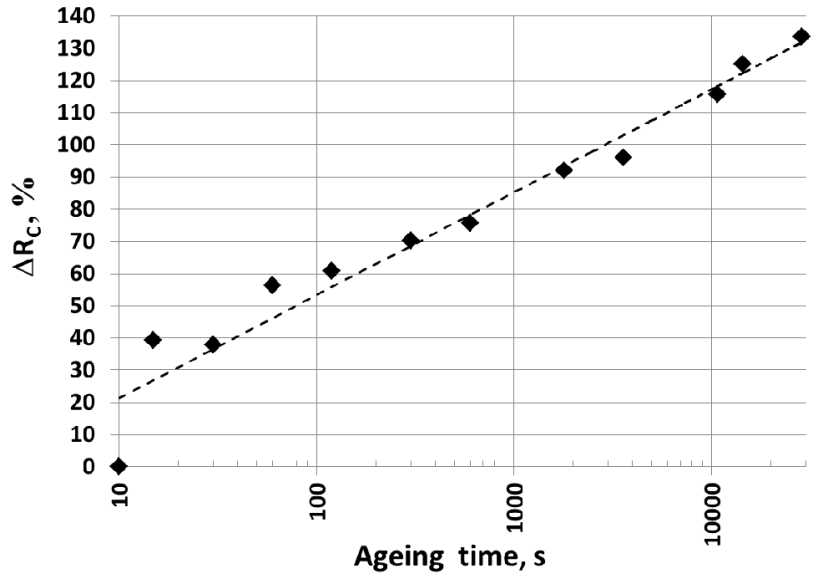

(b)

Fig. 4. (a) Yield strength $R_{C}$ versus ageing time. MS350 maraging steel subjected to ageing at $480^{\circ} \mathrm{C}$ for 15 seconds to 8 hours; (b) Increase in $R_{C}$ with ageing time referred to solution heat treated state 


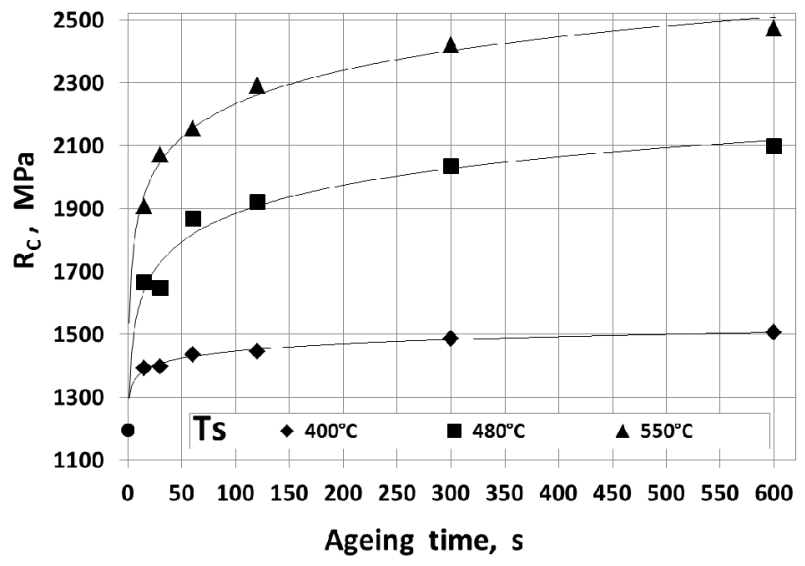

(a)

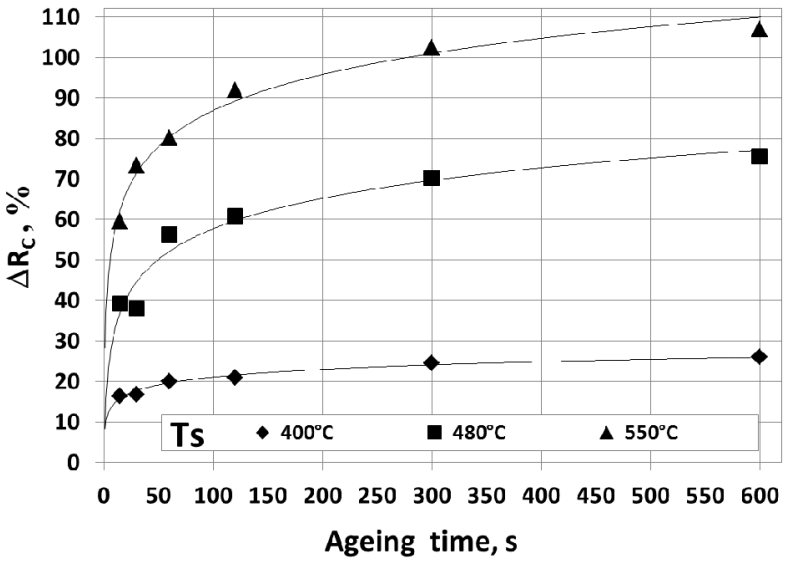

(b)

Fig. 5. (a) Yield strength versus ageing time. MS350 maraging steel subjected to ageing at $400^{\circ} \mathrm{C}, 480^{\circ} \mathrm{C}$ and $550^{\circ} \mathrm{C}$ for time from 15 seconds to 600 seconds; (b) Increase in $R_{C}$ during ageing referred to solution heat treated state

$50 \mathrm{HRC}$ (ca. $600 \mathrm{HV}$ ) after ageing at temperature of $480^{\circ} \mathrm{C}$ for 300 seconds was reached. Results of hardness measurements after ageing at temperatures of $400^{\circ} \mathrm{C}, 480^{\circ} \mathrm{C}$ and $550^{\circ} \mathrm{C}$ for time up to 600 seconds are presented in Fig. 7. Ageing at temperature of $550^{\circ} \mathrm{C}$ during 30 seconds causes increase in hardness up to ca. $50 \mathrm{HRC}(600 \mathrm{HV})$ and after 600 seconds hardness reaches the value of $56 \mathrm{HRC}$ (ca. $670 \mathrm{HV}$ ). Hardness after ageing at temperature of $550^{\circ} \mathrm{C}$ for 600 seconds is comparable to hardness obtained for standard parameters of ageing. Hardness of ca. $42 \mathrm{HRC}(480 \mathrm{HV})$ after ageing at temperature of $400^{\circ} \mathrm{C}$ for 600 seconds was obtained.

Heat Treatment in Dilatometer. Short-time ageing was conducted in dilatometer at temperature of $480^{\circ} \mathrm{C}$ and $550^{\circ} \mathrm{C}$ during $10 \mathrm{~s}, 20 \mathrm{~s}$ and $30 \mathrm{~s}$. Additionally samples were subjected

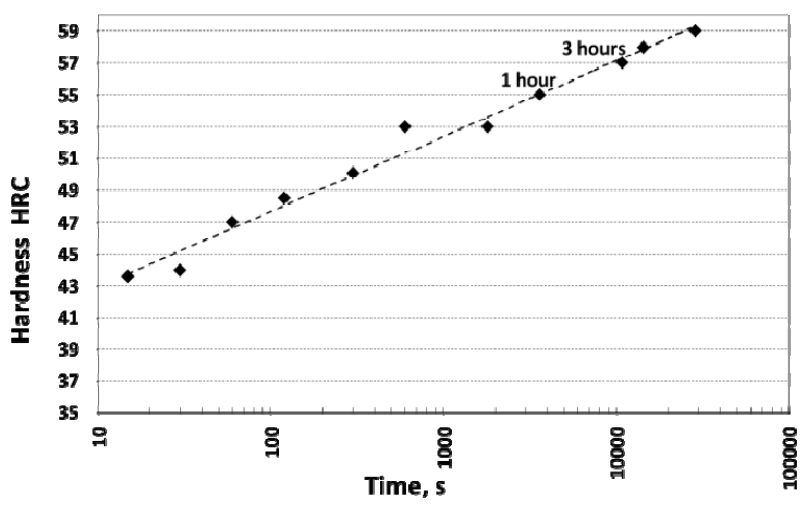

(a)

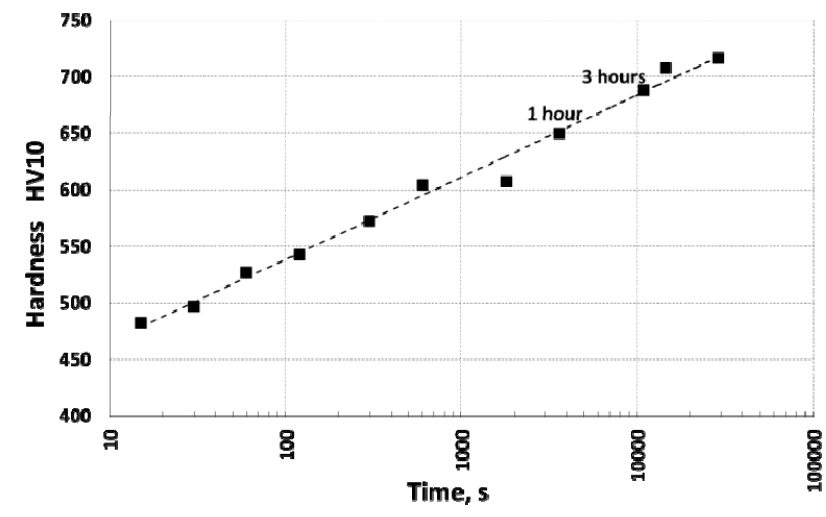

(b)

Fig. 6. Results of hardness HRC (a) and HV10 (b) measurements of MS350 maraging steel subjected to ageing at temperature of $480^{\circ} \mathrm{C}$ for 15 seconds to 8 hours

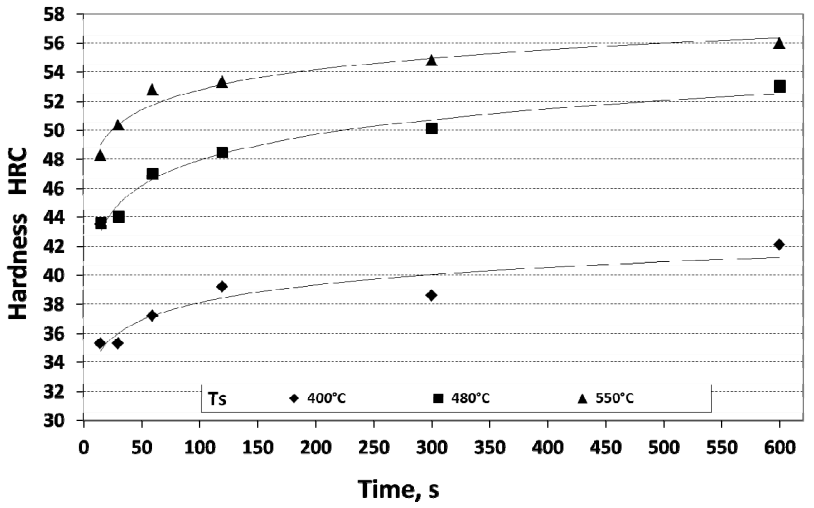

(a)

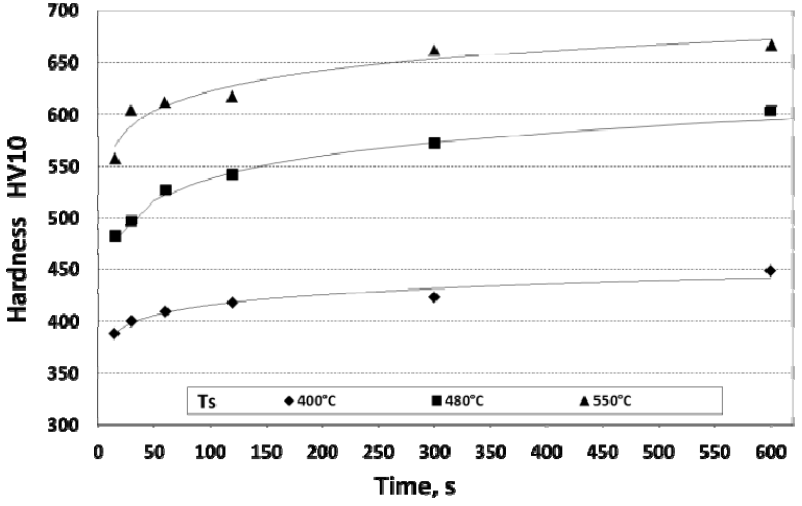

(b)

Fig. 7. Results of HRC (a) and HV10 (b) hardness measurements of MS350 maraging steel subjected to ageing at temperatures of $400^{\circ} \mathrm{C}, 480^{\circ} \mathrm{C}$ and $550^{\circ} \mathrm{C}$ for time up to 600 seconds 


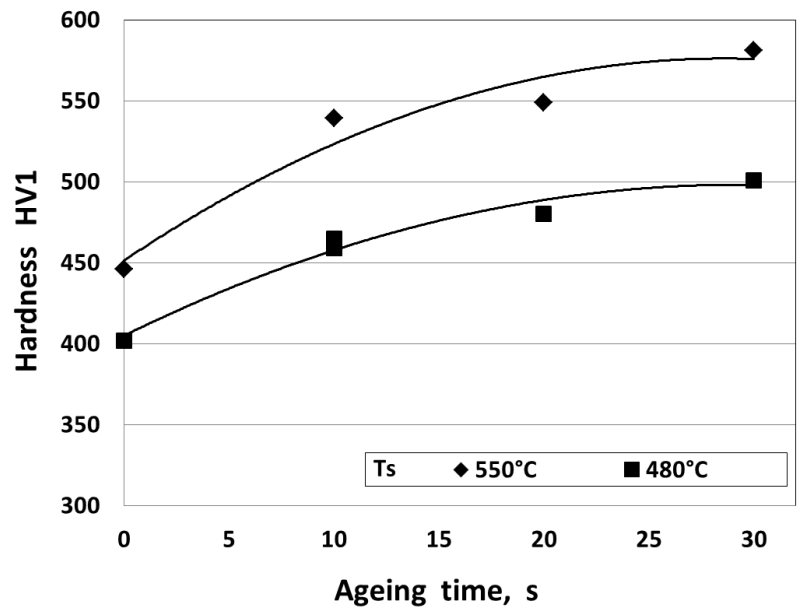

(a)

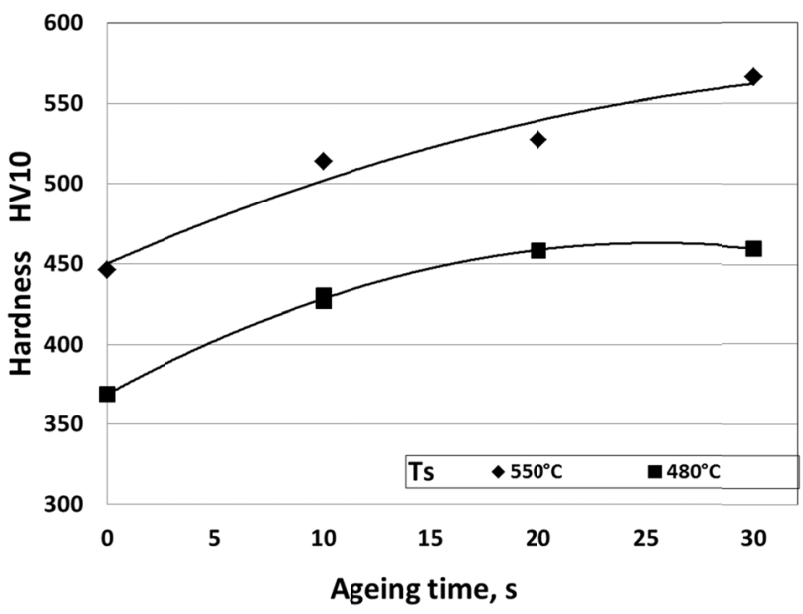

(b)

Fig. 8. Results of Vickers HV1 (a) and HV10 (b) hardness measurements of MS350 maraging steel subjected to ageing in dilatometer

to impulse heating to the temperature of ageing and immediately after reaching the required temperature samples were cooled to room temperature. Vickers hardness measurements after heat treatment in dilatometer were conducted. Results of hardness measurements are presented in Fig. 8. The obtained values are close to those measured following heat treatment with application of the same parameters in Gleeble simulator. After ageing at temperature of $550^{\circ} \mathrm{C}$ for 10 seconds hardness reached the level of $500 \mathrm{HV}$ and for 30 seconds hardness increased above $550 \mathrm{HV}$.

Results of Mechanical Properties in Static Tensile Tests and Hardness Measurements. Parameters of ageing of specimens selected for tensile tests based on the analysis of compression curves are presented in Table 3. Table 3 includes also results of measurements of mechanical properties and hardness of samples following short-time ageing.

TABLE 3

Mechanical properties of maraging MS350 steel determined in static tensile test and results of hardness measurements

\begin{tabular}{|c|c|c|c|c|c|}
\hline $\begin{array}{c}\text { Temperature } \\
\text { / time } \\
\text { of ageing }\end{array}$ & $\begin{array}{c}\text { YS } \\
\text { MPa }\end{array}$ & $\begin{array}{c}\text { UTS } \\
\text { MPa }\end{array}$ & $\begin{array}{c}\text { A } \\
\%\end{array}$ & $\begin{array}{c}\text { Average value } \\
\text { of hardness } \\
\text { HRC }\end{array}$ & $\begin{array}{c}\text { Std. } \\
\text { deviation of } \\
\text { hardness }\end{array}$ \\
\hline $\begin{array}{c}480^{\circ} \mathrm{C} / 4 \\
\text { hours }\end{array}$ & 2300 & 2400 & 4.0 & 57 & 0.4 \\
\hline $\begin{array}{c}480^{\circ} \mathrm{C} / 30 \\
\text { minutes }\end{array}$ & 1877 & 2011 & 4.0 & 52 & 0.8 \\
\hline $\begin{array}{c}480^{\circ} \mathrm{C} / 30 \\
\text { minutes }\end{array}$ & 1896 & 2004 & 5.2 & 53 & 0.4 \\
\hline $\begin{array}{c}550^{\circ} \mathrm{C} / 120 \\
\text { seconds }\end{array}$ & 1935 & 2039 & 7.5 & 53 & 0.4 \\
\hline $\begin{array}{c}550^{\circ} \mathrm{C} / 120 \\
\text { seconds }\end{array}$ & 1918 & 2055 & 7.5 & 53 & 0.8 \\
\hline $\begin{array}{c}550^{\circ} \mathrm{C} / 300 \\
\text { seconds }\end{array}$ & 2083 & 2157 & 7.2 & 54 & 1.1 \\
\hline $\begin{array}{c}550^{\circ} \mathrm{C} / 300 \\
\text { seconds }\end{array}$ & 2095 & 2173 & 7.5 & 54 & 0.8 \\
\hline $\begin{array}{c}550^{\circ} \mathrm{C} / 600 \\
\text { seconds }\end{array}$ & 2082 & 2231 & 8.0 & 55 & 0.4 \\
\hline $\begin{array}{c}550^{\circ} \mathrm{C} / 600 \\
\text { seconds }\end{array}$ & 2167 & 2245 & 7.2 & 54 & 1.5 \\
\hline
\end{tabular}

Reference material subjected to standard ageing was characterised by hardness of 56-58 HRC, yield strength ca. $2300 \mathrm{MPa}$ and tensile strength ca. $2400 \mathrm{MPa}$ as well as total elongation of ca. $4.0 \%$. After short-time ageing at temperature of $550^{\circ} \mathrm{C}$ during time from 120 to 600 seconds hardness from 52 to $55 \mathrm{HRC}$, YS from 1918 to $2167 \mathrm{MPa}$ and UTS from 2039 to $2245 \mathrm{MPa}$ respectively at total elongation $7.2-8.0 \%$ were obtained. Samples subjected to short-time ageing at temperature of $550^{\circ} \mathrm{C}$ showed improved strength properties and elongation as compared to samples subjected to ageing at temperature of $480^{\circ} \mathrm{C}$ for 30 minutes.

Initial tests of thermal stability of properties obtained as a result of short-time ageing were conducted. After ageing at temperature of $550^{\circ} \mathrm{C}$ during 600 seconds the material was held during 48 hours at temperature of $180^{\circ} \mathrm{C}$ and no change in hardness was ascertained. These tests will be continued in order to define thermal stability of other properties in particular impact toughness. Results of hardness measurements of MS350 maraging steel after short-time ageing and additional holding at temperature of $180^{\circ} \mathrm{C}$ are presented in Table 4 .

TABLE 4

Results of hardness measurements of MS350 maraging steel subjected to ageing at temperature of $550^{\circ} \mathrm{C}$ for 600 seconds and held at temperature of $180^{\circ} \mathrm{C}$ for 48 hours

\begin{tabular}{|c|c|c|}
\hline $\begin{array}{c}\text { Parameters of heat treatment } \\
\boldsymbol{T}_{\boldsymbol{s}} / \boldsymbol{t}_{\boldsymbol{s}}\end{array}$ & $\begin{array}{c}\text { Range of } \\
\text { hardness HV10 }\end{array}$ & Average value \\
\hline $550^{\circ} \mathrm{C} / 600$ seconds & $650-660$ & $\begin{array}{c}650 \mathrm{HV} 10 \\
(56 \mathrm{HRC})\end{array}$ \\
\hline $\begin{array}{c}550^{\circ} \mathrm{C} / 600 \text { seconds }+ \\
180^{\circ} \mathrm{C} / 48 \text { hours }\end{array}$ & $642-664$ & $\begin{array}{c}653 \mathrm{HV} 10 \\
(56 \mathrm{HRC})\end{array}$ \\
\hline
\end{tabular}

\subsection{Results of notch impact toughness measurements}

Material aged at temperature of $550^{\circ} \mathrm{C}$ during: 120,300 , 600 seconds and subjected to impulse heating (I) as well as reference material after standard ageing at temperature of $480^{\circ} \mathrm{C}$ 
during 4 hours was prepared for tests. Results of notch impact toughness measurements are presented in Table 5. Impact toughness of MS350 maraging steel subjected to ageing at the temperature of $480^{\circ} \mathrm{C}$ for 4 hours determined at room temperature was ca. $16 \mathrm{~J} / \mathrm{cm}^{2}$ and dropped to ca. $11 \mathrm{~J} / \mathrm{cm}^{2}$ at temperature of $-40^{\circ} \mathrm{C}$. For samples subjected to ageing at temperature of $550^{\circ} \mathrm{C}$ for time up to 600 seconds higher impact toughness was obtained which reached from 20 to $25 \mathrm{~J} / \mathrm{cm}^{2}$ at room temperature and ca. $20 \mathrm{~J} / \mathrm{cm}^{2}$ at temperature of $-40^{\circ} \mathrm{C}$. Results of measurements indicated that MS350 maraging steel following short-time ageing is characterised by impact toughness level which is ca. twice higher at the temperature of $-40^{\circ} \mathrm{C}$ than impact toughness of material subjected to standard ageing. Samples aged at temperature of $550^{\circ} \mathrm{C}$ during time up to 300 seconds have shown the highest level of impact toughness at room temperature. For sample subjected to ageing at temperature of $550^{\circ} \mathrm{C}$ during 600 seconds a slight drop in impact toughness at room temperature to ca. $20 \mathrm{~J} / \mathrm{cm}^{2}$ occurred.

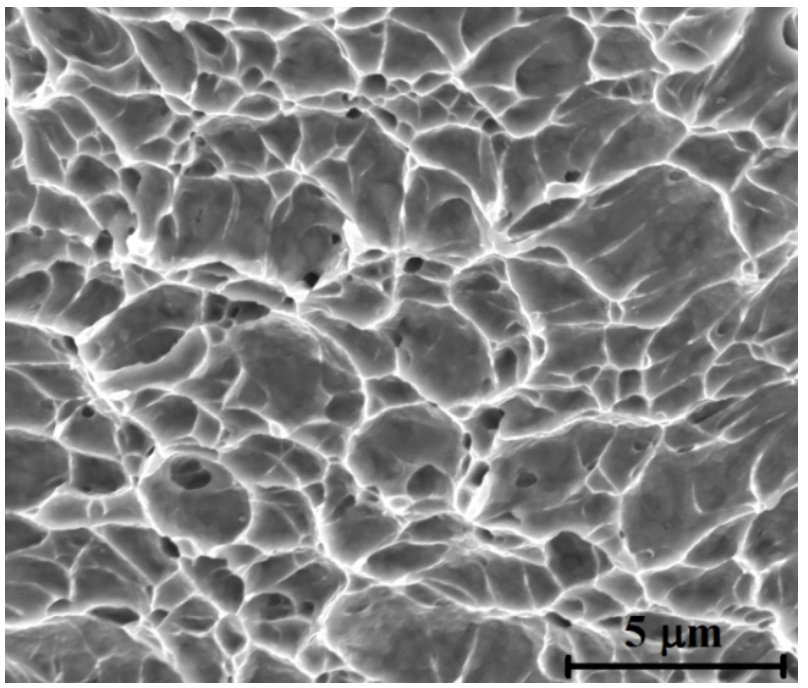

(a)

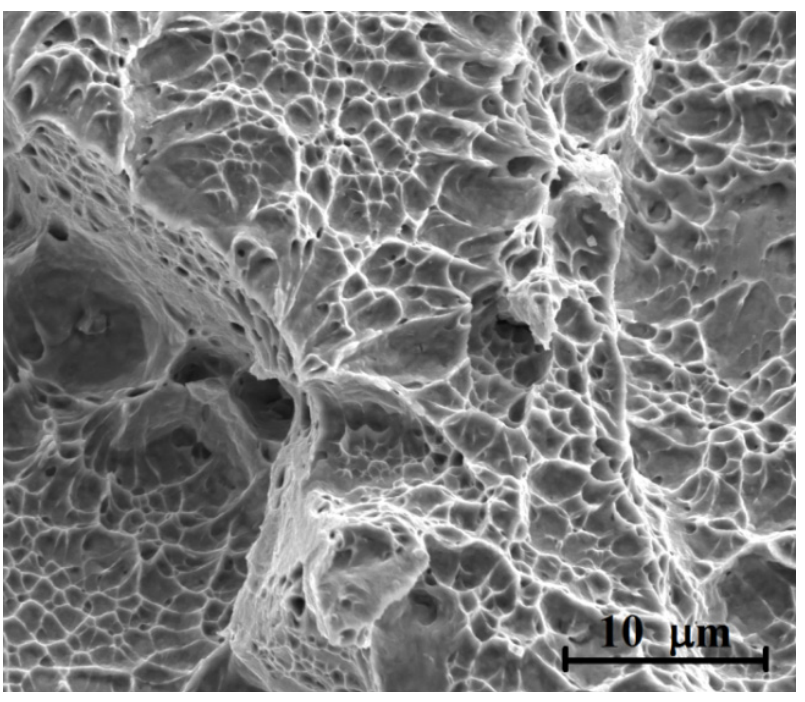

(b)
TABLE 5

Results of notch impact toughness measurements of MS350 maraging steel

\begin{tabular}{|c|c|c|}
\hline \hline \multirow{2}{*}{$\begin{array}{c}\text { Ageing parameters } \\
\boldsymbol{T}_{\boldsymbol{s}} / \boldsymbol{t}_{\boldsymbol{s}}\end{array}$} & \multicolumn{2}{|c|}{ Charpy-V impact toughness, $\mathbf{J} / \mathbf{c m}^{\mathbf{2}}$} \\
\cline { 2 - 3 } & \multicolumn{2}{|c|}{ Test temperature } \\
\cline { 2 - 3 } & $\mathbf{+ 2 2 ^ { \circ } \mathbf { C }}$ & $-\mathbf{4 0} \mathbf{C}^{\circ} \mathbf{C}$ \\
\hline $480^{\circ} \mathrm{C} / 4$ hours & 16 & 11 \\
\hline $550^{\circ} \mathrm{C} / \mathrm{I} *$ & 25 & 21 \\
\hline $550^{\circ} \mathrm{C} / 120$ seconds & 24 & 20 \\
\hline $550^{\circ} \mathrm{C} / 300$ seconds & 24 & 20 \\
\hline $550^{\circ} \mathrm{C} / 600$ seconds & 20 & 20 \\
\hline
\end{tabular}

${ }^{*)} \mathrm{I}$ - impulse heating

\subsection{Results of surface fracture examinations}

Material aged at temperature of $550^{\circ} \mathrm{C}$ was selected for examinations of rupture surface in static tensile test. Fig. 9 presents microphotographs illustrating rupture surface morphology. The examined material differing in the time of ageing which ranged from 120 to 600 seconds was characterised by ductile fracture without presence of areas that would indicate brittle cracking. In particular precipitates correlated with structural elements of fracture were not found. Based on the observations in scanning electron microscope only single non-metallic inclusions were found.

\subsection{Results of microstructure examinations using transmission electron microscope}

Based on the results of mechanical properties measurements variants for examination of microstructure using transmission electron microscope Titan 80-300 were selected. For examination in TEM cylindrical samples of diameter $3 \mathrm{~mm}$ were subjected to ageing at temperature of $550^{\circ} \mathrm{C}$ during 120 and

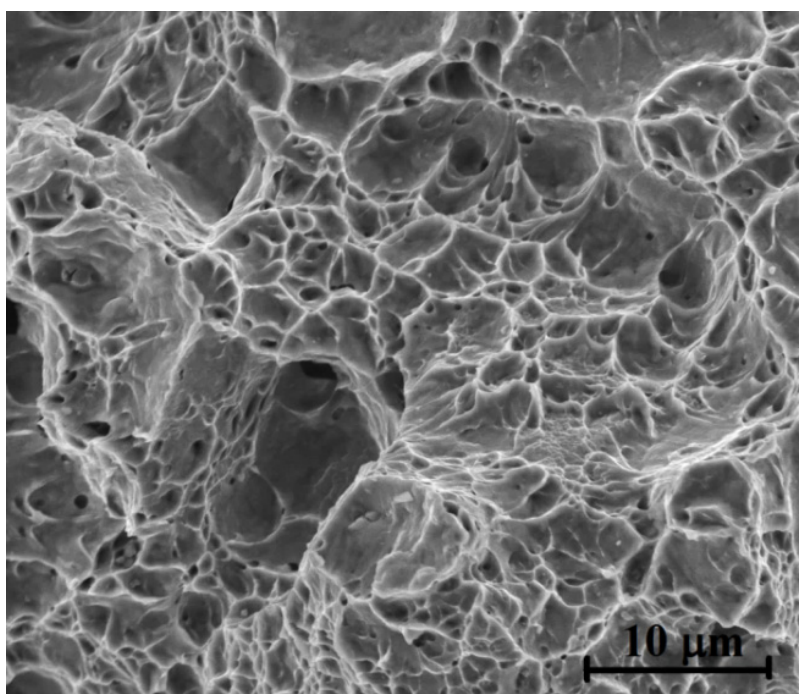

(c)

Fig. 9. Surfaces of samples' rupture in tensile tests. MS350 maraging steel after short-time ageing at temperature of $550^{\circ} \mathrm{C}$ during: 120 seconds (a); 300 seconds (b) and 600 seconds (c) 
600 seconds. After heat treatment thin foils were prepared by means of electrolytic thinning and ion thinning using FIB device (Quanta 3D 200i). Results of hardness measurements for the material of which thin foils were prepared for TEM examinations are presented in Table 6.

TABLE 6

Parameters of ageing and results of hardness measurements of samples of MS350 maraging steel examined using TEM

\begin{tabular}{|c|c|c|}
\hline \hline $\begin{array}{c}\text { Ageing parameters } \\
\boldsymbol{T}_{\boldsymbol{s}} / \boldsymbol{t}_{\boldsymbol{s}}\end{array}$ & $\begin{array}{c}\text { Average value of } \\
\text { hardness HV10 }\end{array}$ & Std. deviation \\
\hline $550^{\circ} \mathrm{C} / 120$ seconds & 612 & 9,6 \\
\hline $550^{\circ} \mathrm{C} / 600$ seconds & 652 & 4,8 \\
\hline
\end{tabular}

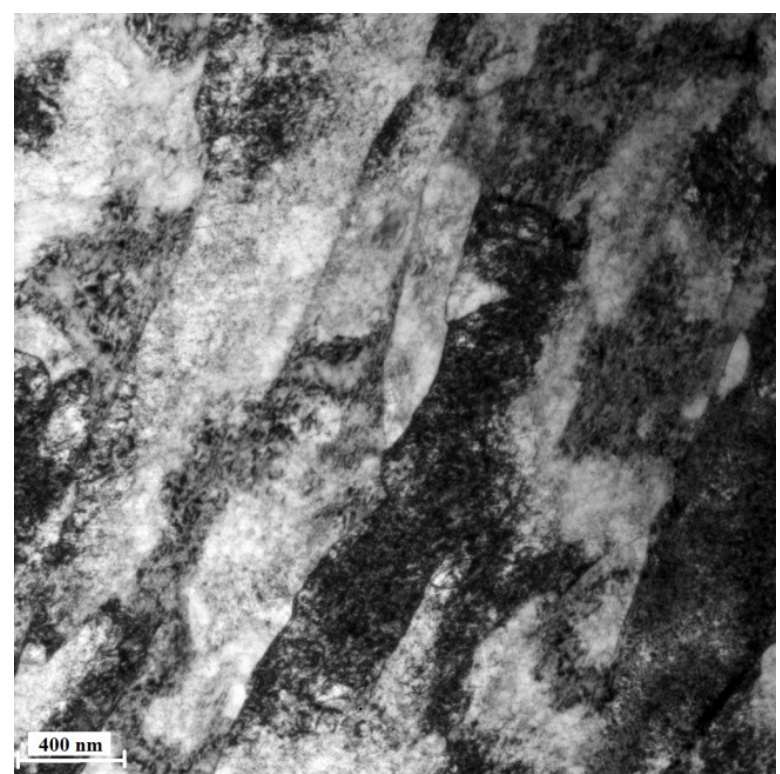

(a)
Results of examinations of microstructure of sample matrix following ageing at temperature of $550^{\circ} \mathrm{C}$ for 120 and 600 seconds are presented in Figure 10. At magnifications up to $100000 \times$ martensite laths of high density of dislocations are visible. At magnifications above $100000 \times$ precipitates of rodlike shape were found. Length of precipitates reached ca. several dozen $\mathrm{nm}$ and dimensions of cross section ca. $5 \mathrm{~nm}$. Fig. 11 presents example of dark field image and electron diffraction pattern of nano-precipitates in MS350 maraging steel subjected to ageing at $550^{\circ} \mathrm{C}$ for 120 seconds.

Example of precipitates in sample aged at $550^{\circ} \mathrm{C}$ during 600 seconds are presented in Figs. 12 and 13. Nano-precipitates of length of several dozen $\mathrm{nm}$ and dimensions of cross section ca. $5 \mathrm{~nm}$ were identified. By means of electron micro-diffraction

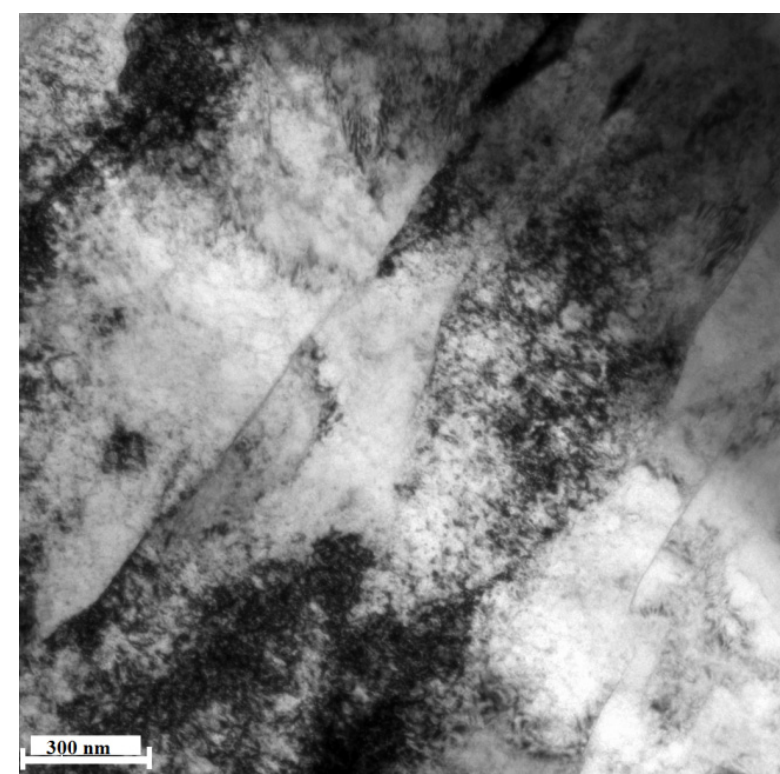

(b)

Fig. 10. Microstructure of MS350 maraging steel matrix after ageing at temperature of $550^{\circ} \mathrm{C}$ for $120 \mathrm{~s}$ (a) and $600 \mathrm{~s}$ (b). Bright field image

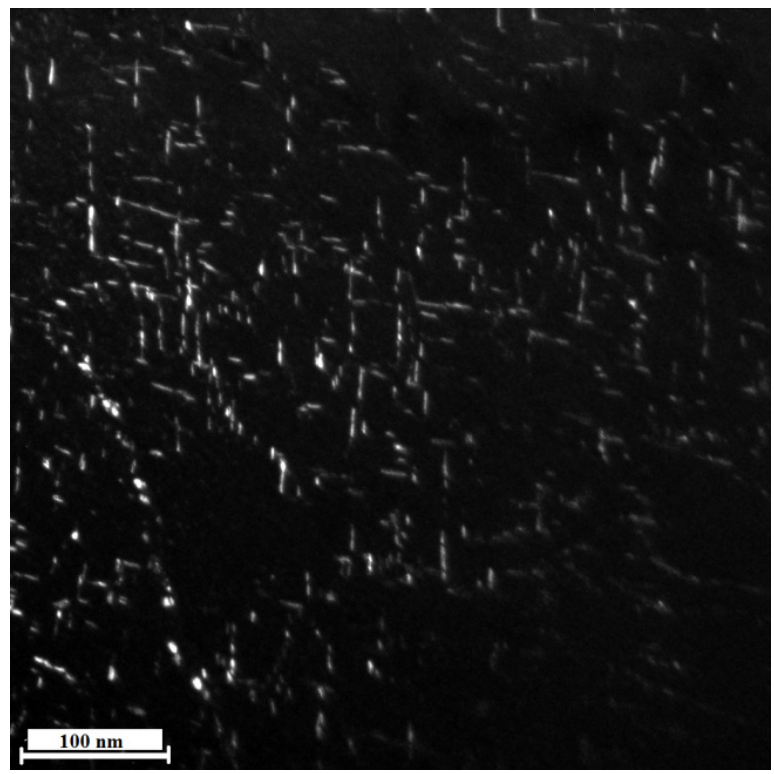

(a)

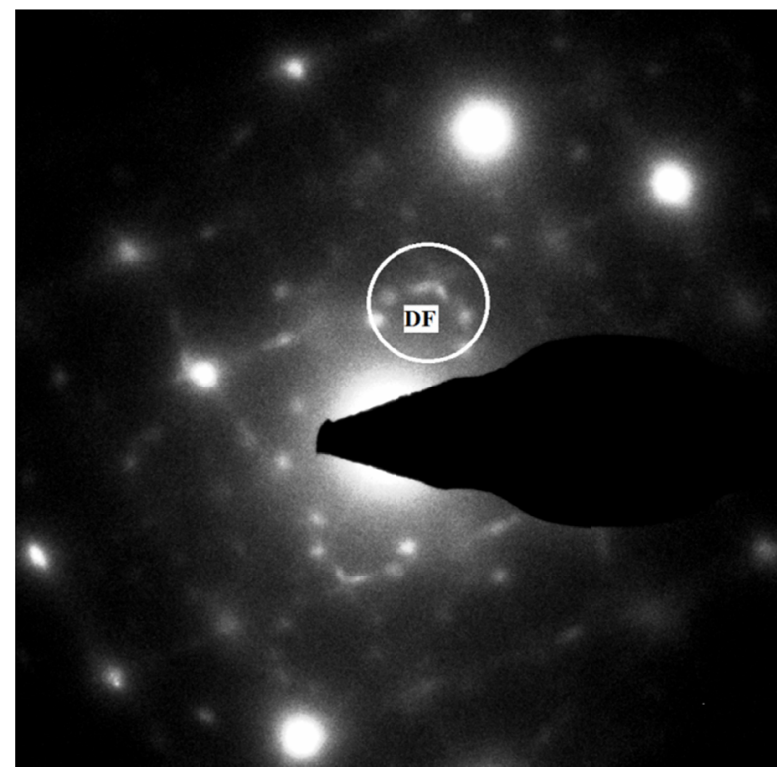

(b)

Fig. 11. (a) Dark field image in reflections of nano-particles marked in Fig. 11b and (b) - electron diffraction pattern 


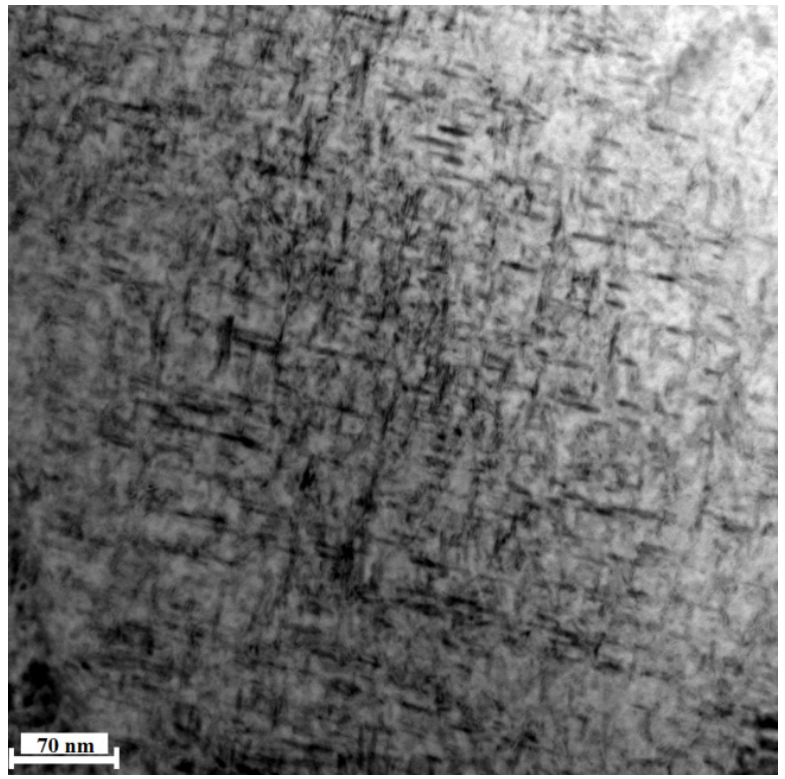

(a)

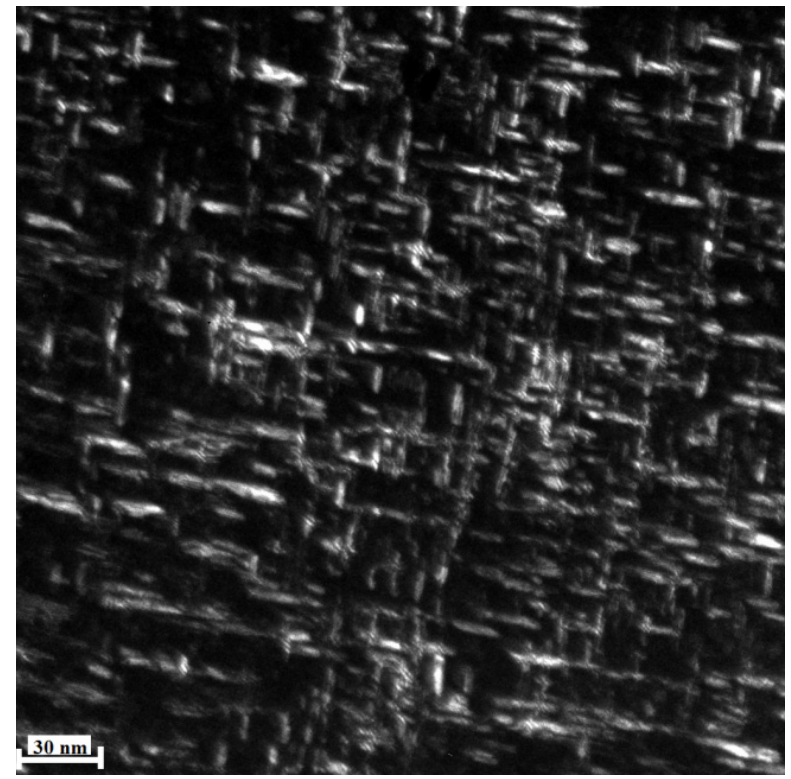

(b)

Fig. 12. Nano-precipitates $\mathrm{Ni}_{3} \mathrm{Mo}$ in MS350 maraging steel after ageing at temperature of $550^{\circ} \mathrm{C}$ for 600 seconds; (a) bright field image; b) dark field image in the reflection of $\mathrm{Ni}_{3} \mathrm{Mo}$ phase

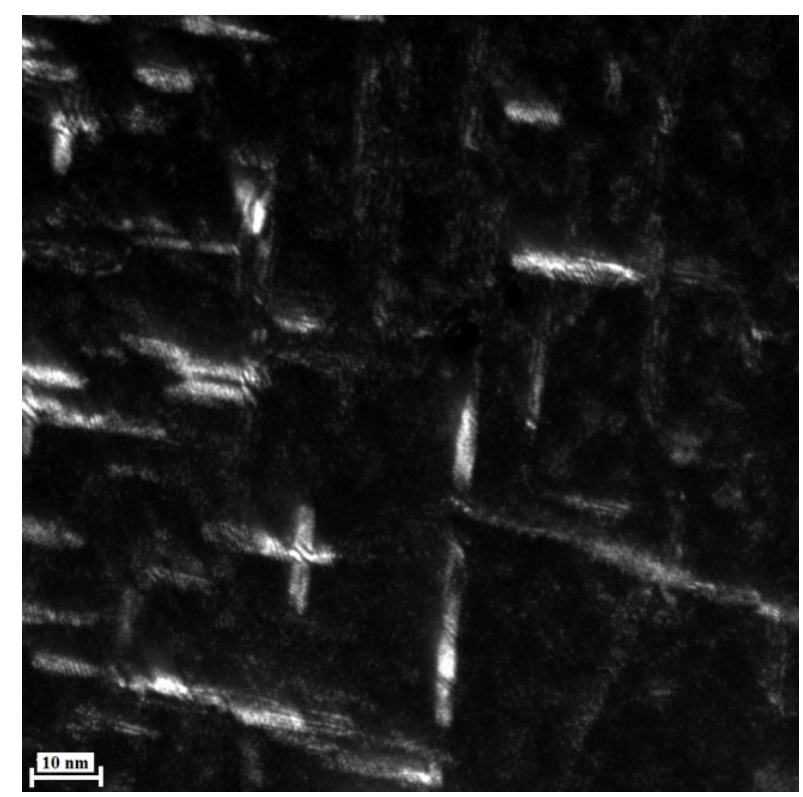

(a)

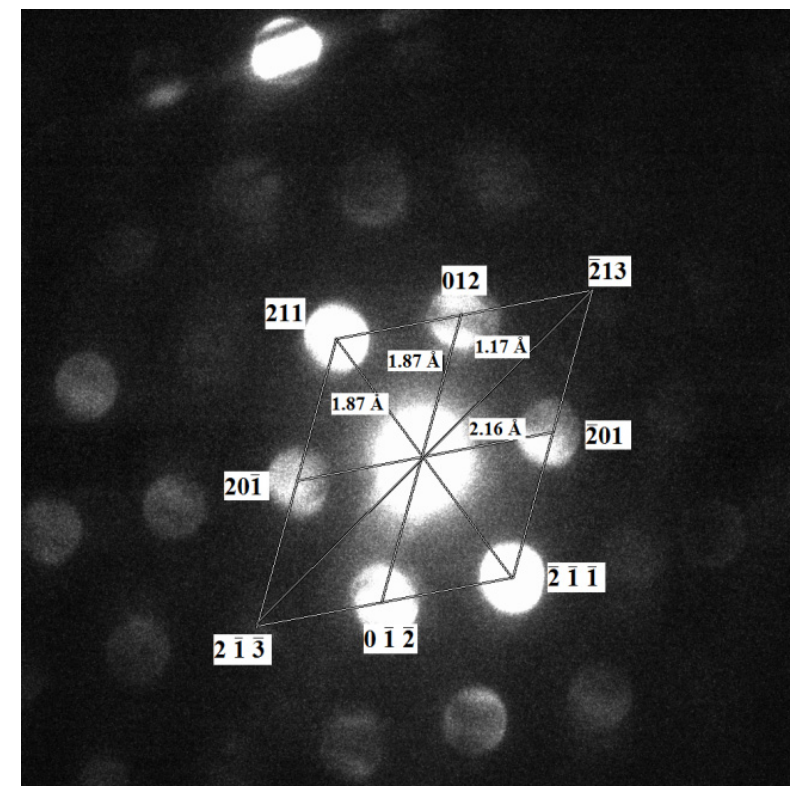

(b)

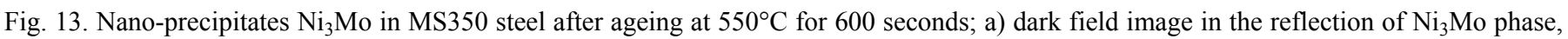
b) electron micro-diffraction pattern of $\mathrm{Ni}_{3} \mathrm{Mo}$, crystal zone orientation [241] $\mathrm{Ni}_{3} \mathrm{Mo}$

technique $\mathrm{Ni}_{3}$ Mo precipitates of orthorhombic crystallographic structure and lattice parameters $a_{o}=5.064 \AA, b_{o}=4.224 \AA$ and $c_{o}=4.448 \AA$ 为 were identified (Fig. 13) [4, 7, 21]. Fig. 14 presents nano-precipitates observed in high resolution mode (HRTEM). These observations confirmed the type of precipitates and their cross-section size of ca. $5 \mathrm{~nm}$. Fig. 15 presents results of spot analysis of chemical composition of precipitates by means of STEM-EDS method. EDS spectra and results of quantitative analysis indicate increased content of $\mathrm{Mo}$ and $\mathrm{Ni}$ in precipitates as compared to matrix. Content of $\mathrm{Ni}$ in precipitates increases ca. twofold and Mo ca. threefold as compared to matrix composition. A confirmation of the increase in content of $\mathrm{Ni}$ and Mo in precipitates are the results of line and surface qualitative analysis of the content of the elements (Figs. 16 and 17). Analysis of chemical composition of nano-precipitates covers also the matrix around them. In the areas of precipitates drop in the content of Fe and Co was observed as compared to the average content thereof in matrix. 


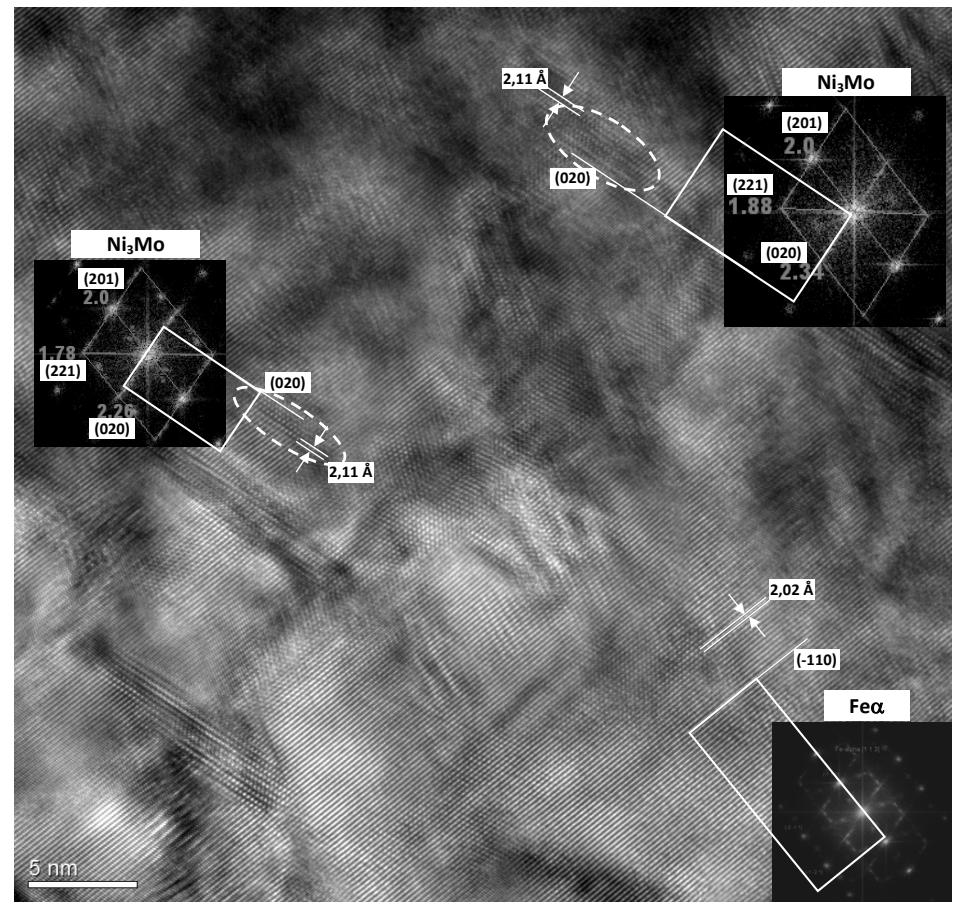

Fig. 14. High-resolution image (HRTEM) of nano-precipitates $\mathrm{Ni}_{3} \mathrm{Mo}$ in MS350 maraging steel aged at temperature of $550^{\circ} \mathrm{C}$ for 600 seconds
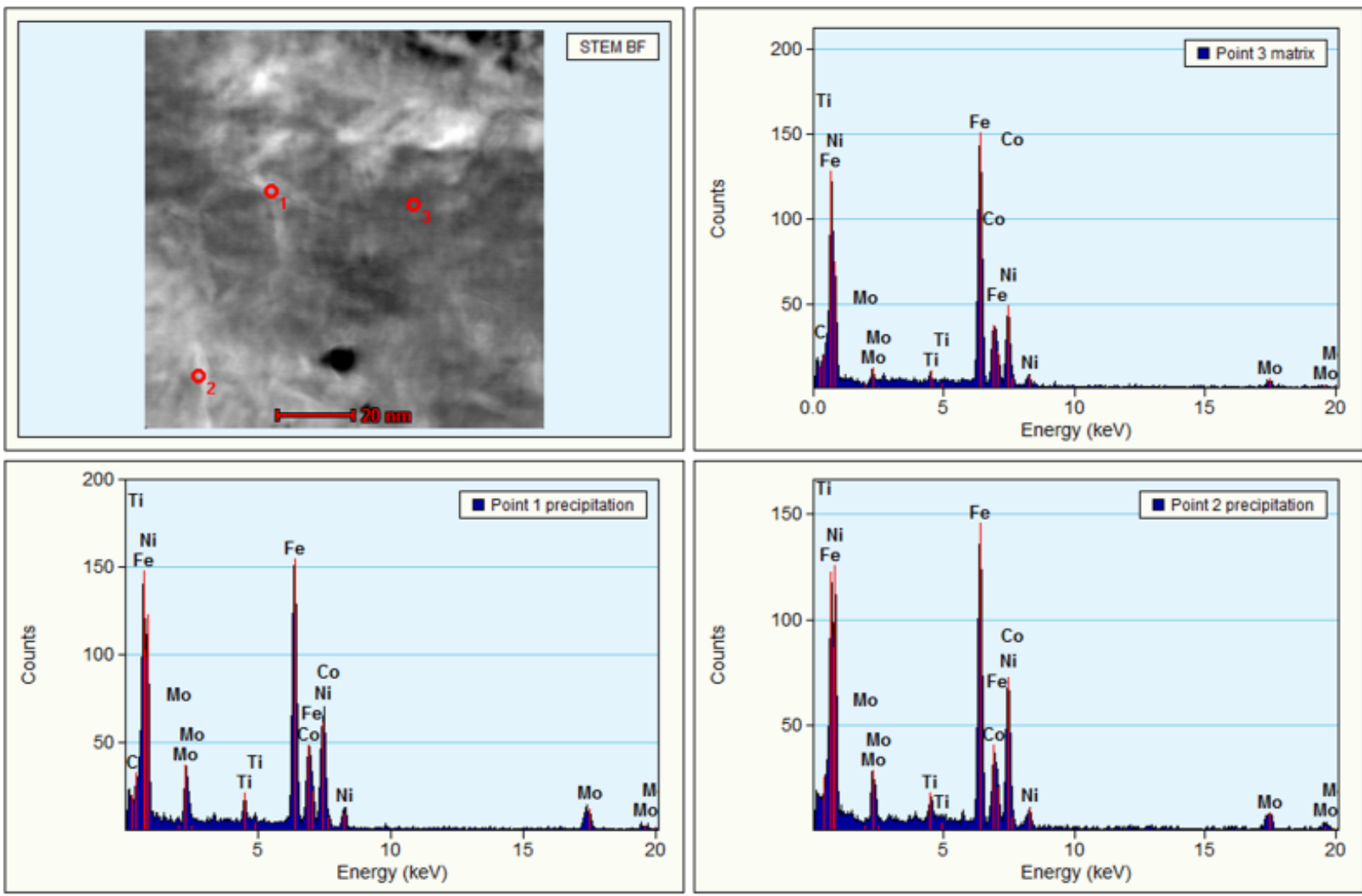

(a) EDS spectra from the areas indicated on the microphotograph; Points 1 and 2 -precipitates, Point 3-matrix

\begin{tabular}{|c|c|c|c|c|c|c|}
\hline \multirow{2}{*}{ Element } & mass\% & atomic\% & mass\% & atomic\% & mass\% & atomic\% \\
\hline & \multicolumn{2}{|c|}{ matrix } & \multicolumn{2}{|c|}{$\begin{array}{l}\text { Precipitate } 1 \\
\end{array}$} & \multicolumn{2}{|c|}{ Precipitate 2} \\
\hline Fe & 66.7 & 68.2 & 51.9 & 54.0 & 51.9 & 54.5 \\
\hline $\mathbf{N i}$ & 14.7 & 14.3 & 23.6 & 23.4 & 28.5 & 28.5 \\
\hline $\mathrm{Co}$ & 12.0 & 11.6 & 12.0 & 11.8 & 10.8 & 10.8 \\
\hline Mo & 3.3 & 2.0 & 10.1 & 6.1 & 7.2 & 4.4 \\
\hline $\mathrm{Ti}$ & 3.3 & 3.9 & 1.8 & 2.2 & 1.5 & 1.9 \\
\hline
\end{tabular}

(b) contents of elements in matrix and in nano-precipitates

Fig. 15. Results of chemical composition microanalysis of nano-precipitates by means of STEM-EDS method 

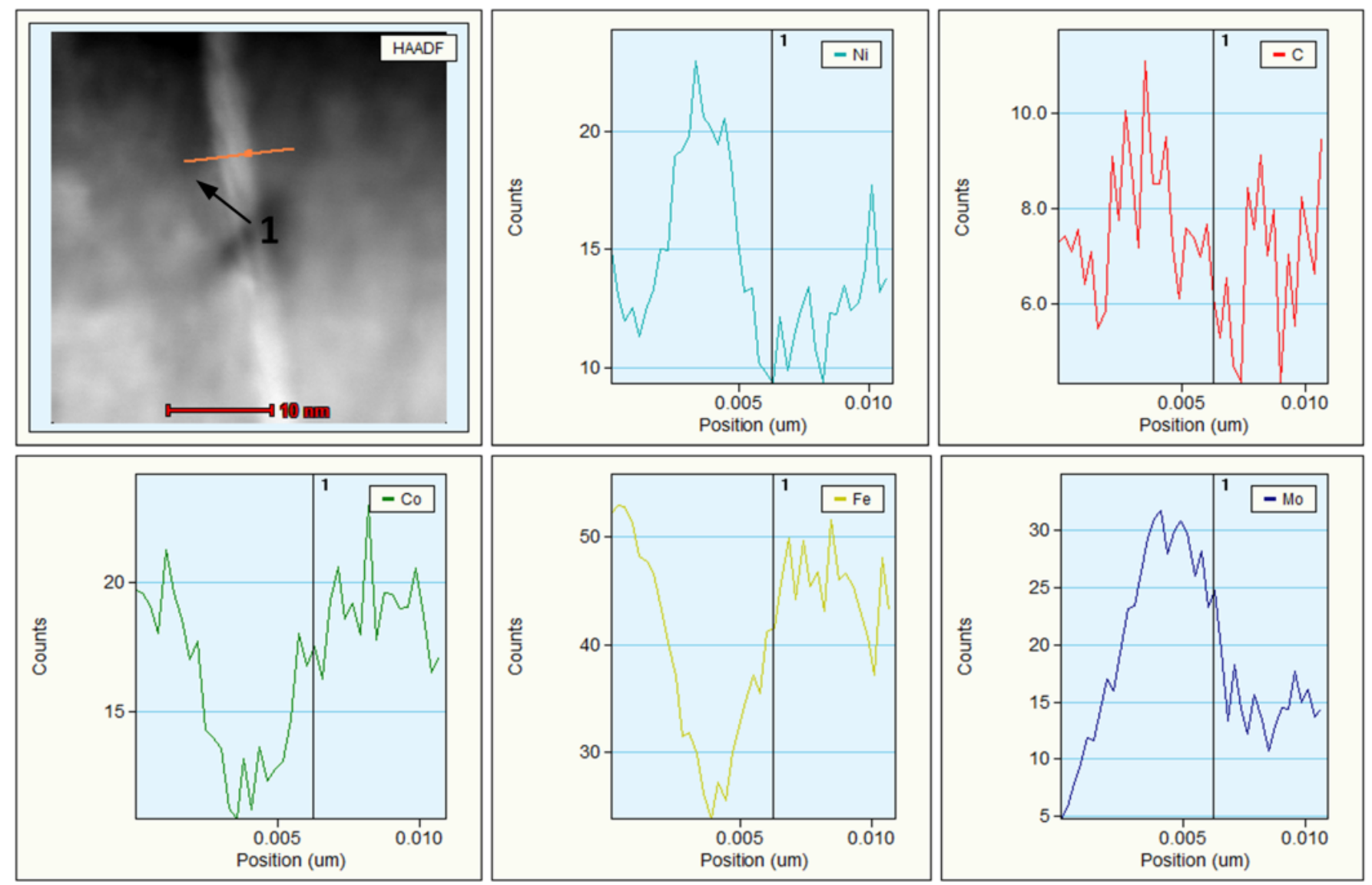

Fig. 16. Line profile of $\mathrm{Ni}, \mathrm{Mo}, \mathrm{Fe}, \mathrm{Co}$ and $\mathrm{C}$ content on the width of precipitate, (along the line indicated on the microphotograph)
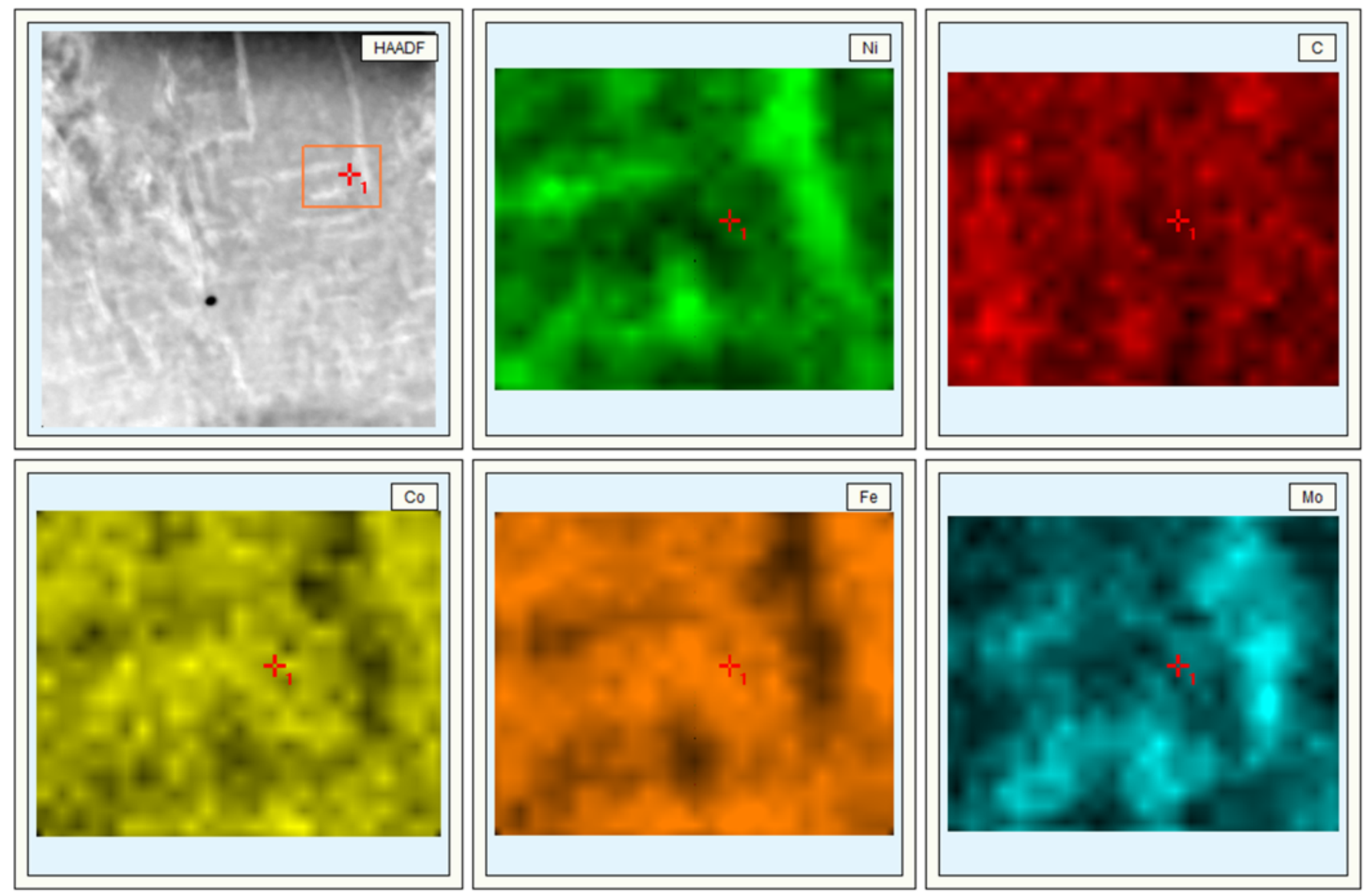

Fig. 17. Surface distribution analysis of $\mathrm{Ni}, \mathrm{Co}, \mathrm{Fe}, \mathrm{Mo}$ and $\mathrm{C}$ content in the area of nano-precipitates, (indicated on the microphotograph) 


\section{Summary and conclusions}

As a result of application of the new heat treatment method consisting in short-time ageing at increased temperature in comparison with standard treatment, higher ductility and improved impact toughness of $18 \mathrm{Ni3} 50$ maraging steel was achieved at slightly lower strength as compared to the condition after standard ageing. Increase in ageing temperature intensifies the process of precipitates nucleation creating the possibility of formation of larger number of clusters. Long times of ageing and lower temperatures create conditions for formation and growth of precipitates in the preferential locations mainly on dislocations. Particles on dislocations by blocking movement thereof improve the strength of steel, simultaneously limiting ability to plastic deformation. Application of higher ageing temperature compare to standard temperature and shortening the time of ageing creates possibilities of intensive homogenous nucleation of precipitates of strengthening phases in supersaturated matrix. Due to short time, the process is interrupted and particles do not grow as well as dislocations are not hindered. Thus material of high strength level and simultaneously good ductility is formed. Improved ductility of steel can arise from moveable, free from precipitates, dislocations in matrix. Examinations of microstructure confirmed that there is no preferentially nucleated precipitates of strengthening intermetallic phases on dislocations and boundaries of martensite laths.

Results of mechanical properties determination after short-time ageing have shown that this type of heat treatment of MS350 maraging steel enables achievement of strength at the level reached after standard ageing however at higher ductility and impact toughness. For optimum variants of short-time ageing from the combination of strength and ductility point of view the following properties were achieved: $\mathrm{YS}=1900-2150 \mathrm{MPa}$; $\mathrm{UTS}=2100-2250 \mathrm{MPa} ; \mathrm{A}=7-8 \%$ and notch impact toughness $\mathrm{KV}=20 \mathrm{~J} / \mathrm{cm}^{2}$ at temperature minus $40^{\circ} \mathrm{C}$.

Microstructure after short-time ageing is composed of martensitic matrix of high density of dislocations and dispersed precipitates of intermetallic phases of rod-like shape. $\mathrm{Ni}_{3} \mathrm{Mo}$ precipitates have been identified in the material subjected to ageing at temperature of $550^{\circ} \mathrm{C}$. Length of precipitates reaches ca. several dozen nanometres and dimensions of cross section below $4 \mathrm{~nm}$.

\section{REFERENCES}

[1] J. Marcisz, W. Burian, M. Adamczyk, Prace Instytutu Metalurgii Żelaza (Transactions of the Instytut Metalurgii Żelaza), 65, no. 2, 2-7, (2013).

[2] J. Marcisz, B. Garbarz, W. Burian, J. Stępień, L. Starczewski, 1834, 27th International Symposium on Ballistics, Freiburg, Germany, (2013).

[3] S. Floreen, Transactions of the ASM. 57, 38 (1964).

[4] G. R. Speich, Transactions of the metallurgical society of AIME 227, 1426 (1963).

[5] A. Magnee, P. Viatour, J.M. Drapier, D. Coutsouradis, L. Habraken, Cobalt 1, 3 (1973).

[6] A.J. Baker, P.R. Swann, Transactions of the ASM 57, 1008 (1964).

[7] S. Saito, P.A. Beck, Transactions of the metallurgical society of AIME 215, 938 (1959).

[8] K. Soeno, T. Kuroda, Transactions ISIJ 10, 369 (1970).

[9] D.T. Peters, Transactions of the metallurgical society of AIME 239, 1981 (1967).

[10] U.K. Viswanathan, G.K. Dey, M.K. Asundi, Metallurgical Transactions A 24A, 2429 (1993).

[11] B. Garbarz, Zmiany struktury zachodzące podczas starzenia martenzytycznej stali N18K9M5T (Structural changes during ageing of N18K9M5T martensitic steel). Ph.D. thesis, AGH University of Technology, Kraków, (1978).

[12] R. Tewari, S. Mazumder, I.S. Batra, G.K. Dey, S. Banerjee, Acta Materialia 48, 1187 (2000).

[13] Z. Guo, W. Sha, D. Li, Materials Science and Engineering A 373 10 (2004).

[14] J.M. Pardal, S.S.M. Tavares, V.F. Terra, M.R. Da Silva, D.R. Dos Santos, Journal of Alloys and Compounds 393, 109 (2005).

[15] W. Sha, Scripta Materialia,42, 549 (2000).

[16] X. Li, Z. Yin, Materials Letters 24, 235 (1995).

[17] K.V. Rajkumara, S. Vaidyanathana, A. Kumara, T. Jayakumara, B. Raja, K.K. Ray, Journal of Magnetism and Magnetic Materials 312, 359 (2007).

[18] E.V. Pereloma, A. Shekhter, M.K. Miller, S.P. Ringer, Acta Materialia 52, 5589 (2004).

[19] A. Shekhter, H.I. Aaronson, M.K. Miller, S.P. Ringer, E.V. Pereloma, Metallurgical and Materials Transactions A 35A, 97, (2004).

[20] J. Marcisz, B. Garbarz, J. Stępień, M. Adamczyk. Sposób krótkotrwałej obróbki cieplnej stali umacnianej wydzieleniowo (Method of short-time heat treatment of precipitation hardened steel). Zgłoszenie patentowe nr. P.401621. 2012 - patent application.

[21] K. Shimazu, H. Okamoto, Trans. JIM 12, 273 (1971). 